\title{
The Influence of Family Based Determinants on Implementation of Re-Admission Policy of Girls After Teenage Pregnancy in Public Secondary Schools in Kitui County
}

\author{
Elizabeth Kalee Musili ${ }^{1} \quad$ Jonathan Muema Mwania ${ }^{2}$ \\ David Musyoki Mulwa ${ }^{3 *}$ \\ 1.South Eastern Kenya University, Kenya \\ 2. Senior Lecturer, Department of Education Psychology, South Eastern Kenya University, Kenya \\ 3. Senior Lecturer, Department of Education Management and Curriculum Studies, \\ Machakos University, P. O. Box 136-90100, Machakos, Kenya
}

\begin{abstract}
This study sought to investigate the influence of family based determinants on implementation of re-admission policy of girls after teenage pregnancy in public secondary schools in Kitui County, Kenya. The study objectives sought to determine the influence of; socio-economic status of parents, principals' opinion on socio-economic status, family size and girls' awareness of the policy on implementation of re-admission policy. The study was based on the critical theory by the Frankfurt school in German. The target population was 275 principals, 275 guidance and counseling teachers and 275 head girls in the 120 girls' schools and 155 co-education schools in Kitui County, Kenya. The study also targeted the County Director of Education and all the 16 sub county directors of education in Kitui County. Using stratified and simple random sampling, a sample of 83 principals, 83 guidance and counseling, and 83 head girls were selected for the study. The County Director of Education was purposively selected while four sub-county directors of Education were selected using simple random sampling. Data was collected using questionnaires. Quantitative data was analyzed using descriptive and inferential statistics. The study established that; there was a statistically significant association between socio-economic status of parents and implementation of re-admission policy of girls after teenage pregnancy. The family size, principals' opinion on the re-admission policy and girls' awareness of the policy significantly determined the implementation of the re-admission policy of girls after teenage pregnancy. The study recommends that; Parents should be sensitized on their role to educate girls the same way they would do to the boy child. This would enhance the implementation of the re-admission policy of girls after teenage pregnancy in public secondary schools in Kitui County, Kenya. Keywords: Co-education school, Re-admission Policy, Socio-Economic Status Teenage Pregnancies
\end{abstract}

DOI: $10.7176 / \mathrm{JEP} / 11-11-02$

Publication date: April $30^{\text {th }} 2020$

\subsection{Introduction}

Policies that support access to education for girls who drop out of school after teenage pregnancy are not only important to the Kenyan government but have been of a major global concern (Omwancha, 2012). Education is basic human right and provides holistic development of all round person (Muema, Kasivu \& Mwanza. (2019). Schools are established with the aim of imparting learners with skills and knowledge to enable them fit in the society even after some learners drop from the school system. Girls are disadvantaged in education and therefore deserve special attention as they drop out more easily than boys because of various reasons, including early marriage, teenage pregnancy, traditions, domestic violence and sexual harassment in the school setting. Girls should therefore be given opportunity to continue with education, which offer them the opportunity to compete favorably with their peers whose school life went uninterrupted. Schools in the $21^{\text {st }}$ century are therefore avenues for transforming learners to better individuals despite the challenges faced during the schooling period (Nguli, Kasivu \& Kamau, 2018).

As girls transit the turbulent stage of adolescent, they increasingly seek to be free from their parents and gain more autonomy (Njagi \& Mwania, 2017). In order to prevent girls from dropping out of school because of pregnancy, the Convention on the Rights of the Child (CRC) committee recommends measures to ensure that pregnant teenagers are given the chance to complete their education by not excluding them and by developing special programs (Mieke, 2006).

According to the United Nations Children's Fund report (2010), tens of millions of girls are not getting basic education across the developing world and especially in the rural and poor areas of Sub Saharan Africa, the Middle East and South Asia due to pre-marital pregnancies among other things. This is because of economic, social and cultural barriers that keep large number of girls in poor countries out of school after teenage pregnancies. In line with supporting pregnant girls, Inziani (2013) study revealed that socio-economic problems are, to a great extent, precursors rather than penalties of pre-marital motherhood. He then suggested that policies need to give emphasis to support services for the young mothers to enable them to recover from social disadvantage. 
Lewis and Lockheed (2007) argue that very little is known about how to successfully attract excluded girls into primary schools and retain them through secondary school. Though useful, existing knowledge on generic problems is unlikely to be sufficient in shaping policies that meet the needs and concerns of parents and children from excluded communities. They further found out that experiences with excluded groups in some countries such as New Zealand and United States of America, showed that traditional incentives were insufficient to attract girls back to school, meaning, extra effort was required to reach them.

Inclusion as a policy has received attention globally through debates, however there are difficulties in its full attainment resulting in piecemeal reforms in many African countries. The re-admission of girls who become pregnant while in school is one of the on-going initiatives to address gender disparities and affirmative action in education in Kenya (Republic of Kenya, 2007). It explains that one of the objectives of the policy is to increase participation of disadvantaged girls and women in education, and ensure gender equity in education. According to Njagi, Mwania, Manyasi and Mwaura (2017) secondary school students are faced with challenges of navigating safely through their adolescence in a world where the culture of sexual immorality is growing fast. The situation of teenage pregnancy and motherhood in Kitui County is at worrying proportions. So many potential girls keep on dropping out of school because of this situation (CDE, Kitui County, 2013). The society has accepted circumstances where a girl can be pregnant while in school and the parents and community consider it as normal. This is contrary to the ancient times when such girls who became pregnant before marriage are treated as outcasts. It was against this background that this study intended to investigate the family based determinants influencing the implementation of re-admission policy of girls' after teenage pregnancy in public secondary schools in Kitui County, Kenya.

\subsection{Statement of problem}

Education for girls is one of the criteria pathways to promote social and economic development of the society. The dropout of girls leads to great financial and material wastage with the nation losing billions of shillings annually in financial, policy and manpower investment (MOE, 2010). Understanding the implementation of the readmission policy could help understand this missing link between the policy and the practice. According to FAWE News (2014) it was evident that there were factors that were hindering the implementation of the re-admission policy. Statistics and data held in the County Education Directors' office in Kitui County, supports the need to investigate the level of implementation of readmission policy of girls' after teenage pregnancy. In the year 2015 Kitui North had a total of 97 girls who had dropped out of school due to teenage pregnancies. Kitui South, Kitui East and Kitui Central had 83, 78 and 65 girls respectively who dropped out within a span of one year. A total of 323 girls had dropped in the whole county. Out of the total number of dropouts, only 42 (13\%) had gone back to school after delivery (CDE Report Kitui, 2015). There was therefore a need to investigate the family based determinants that influence the implementation of re-admission policy of girls' after teenage pregnancy in public secondary schools in Kitui County, Kenya.

\subsection{Purpose of the study}

The purpose of the study was to investigate the extent to which family based factors have influenced implementation of re-admission policy of girls after teenage pregnancy in Kitui County, Kenya. Specifically, the study is to establish the extent to which parent's socio-economic, principal's opinion, family size and awareness of the girls and has influenced the implementation of girl's re-admission policy after teenage pregnancy.

1.4 Research Objectives

The objectives of the study were to:

1. Determine the Influence of Parents' Socio-economic Status on the Implementation of Girls' Re-admission policy in Kitui County, Kenya

2. Establish the influence of Principals' opinion on socio-economic status of parents on implementation of girls' re-admission policy in Kitui County, Kenya

3. Determine the Influence of Family Size on Implementation of Re-admission policy of girls in Kitui County, Kenya

4. To establish the influence of girls' awareness of the policy on Implementation of Re-admission policy of girls in Kitui County, Kenya

1.5 Research Hypotheses.

This study was guided by the following hypothesis:

$\mathrm{H}_{01}$ : There is no statistically significant association between Parents' Socio-economic Status and implementation of re-admission policy of girls after teenage pregnancy in public secondary schools.

$\mathrm{H}_{02}$ : There is no statistically significant relationship between Principals' opinion on parents' socio-economic status and implementation of girls' re-admission policy after teenage pregnancy in public secondary schools. 
$\mathrm{H}_{03}$ : There is no statistically significant relationship between family size and implementation of re-admission policy of girls after teenage pregnancy in public secondary schools.

$\mathrm{H}_{04}$ : There is no statistically significant association between girls' awareness of the policy and implementation of re-admission policy of girls' after teenage pregnancy in public secondary schools.

\subsection{Research Methodology}

The study adopted a descriptive survey design to investigate determinants that influence the implementation of readmission policy of girls after teenage pregnancy in public secondary schools in Kitui County, Kenya. The target population was 275 principals, 275 guidance and counseling teachers and 275 head girls in the 120 girls' schools and 155 co-education schools in Kitui County, Kenya. The study also targeted the County Director of Education and all the 16 sub county directors of education in Kitui County. Using stratified and simple random sampling, a sample of 83 principals, 83 guidance and counseling, and 83 head girls were selected for the study. The County Director of Education was purposively selected while four sub-county directors of Education were selected using simple random sampling. Data was collected using questionnaires, document review and interview. Quantitative data was done using descriptive and inferential statistics while qualitative data was analyzed thematically.

\subsection{Research Findings and Discussions}

The Principals who responded to the questionnaire were 65, 65 guidance and counseling teachers and 65 head girls. In order to establish the extent to which implementation of re-admission policy of girls after teenage pregnancy in public secondary schools in Kitui county has been done, the respondents were required to indicate the socioeconomic status of the parents to the girls who had been re-admitted after pregnancy.

Table 1 Parents social-economic status

\begin{tabular}{lllllllll}
\hline Principal & & & Students & \multicolumn{5}{c}{$\begin{array}{l}\text { Guidance and counseling } \\
\text { Teachers }\end{array}$} \\
\hline Socio-Economic Status & Frequency & $\%$ & Frequency & $\%$ & \multicolumn{2}{c}{ Frequency $\%$} & Total \% \\
\hline Financially unstable & 15 & 23.1 & 10 & 15.4 & 10 & 35 & 15.4 & 17.9 \\
Financially stable & 20 & 30.8 & 30 & 46.2 & 28 & 78 & 43.1 & 40.0 \\
Educated & 22 & 33.8 & 18 & 27.7 & 21 & 61 & 32.3 & 31.3 \\
Uneducated & 8 & 12.3 & 7 & 10.7 & 6 & 21 & 9.2 & 10.8 \\
\hline
\end{tabular}

Table 1 revealed that majority (40\%) of the respondents indicated that, most of the girls who had been readmitted after teenage pregnancy were from financially stable families. This was followed by $31.3 \%$ who indicated that, they were from educated families. The least were those from financially unstable families $(17.9 \%)$. This shows that the social-economic status influenced the re-admission of girls after teenage pregnancy with most of the needy parents not taking their daughters back to school. These results agree with Nyakio (2011) who argued that poverty was the central cause of teenage pregnancy and that financial constraint was a reason why most girls engaged in premarital sex.

Table 2: Chi-Square Tests for Parents' Socio-economic status and Implementation of re-admission of girls after teenage pregnancy.

\begin{tabular}{llll}
\hline & Value & Df & Asymp. Sig. (2-sided) \\
\hline Pearson Chi-Square & $40.000(\mathrm{a})$ & 4 & .000 \\
Likelihood Ratio & 15.881 & 4 & .003 \\
Linear-by-Linear Association & 16.840 & 1 & .000 \\
N of Valid Cases & 65 & &
\end{tabular}

Table 2 shows that the Pearson Chi-Square is $\chi_{(1,4)}^{2}=40.000, p=.000$. This tells us that there is a statistically significant association between socio-economic status and implementation of re-admission policy of girls after teenage pregnancy. We do therefore reject $\mathrm{H}_{01}$.

Further, the principals were requested to indicate their level of agreement with the statements on the influence of socio- economic status on re-admission policy of teenage girls after pregnancy using a 5-Point Likert scale as; SA for Strongly Agree, A for Agree, N for Neutral, D for Disagree and SD Strongly Disagree. 
Table 3: Principals opinion on socio-economic status and re-admission policy.

\begin{tabular}{|c|c|c|c|c|c|c|c|c|c|c|c|c|}
\hline \multirow[b]{2}{*}{ Statement } & \multicolumn{2}{|c|}{$\mathrm{SA}$} & \multicolumn{2}{|l|}{ A } & \multicolumn{2}{|l|}{$\mathrm{N}$} & \multicolumn{2}{|c|}{ D } & \multicolumn{2}{|c|}{$\mathrm{SD}$} & \multicolumn{2}{|c|}{ Total } \\
\hline & $\mathrm{F}$ & $\%$ & $\mathrm{~F}$ & $\%$ & $\mathrm{~F}$ & $\%$ & $\mathrm{~F}$ & $\%$ & $\mathrm{~F}$ & $\%$ & $\mathrm{~F}$ & $\%$ \\
\hline $\begin{array}{l}\text { Educated parents adhere } \\
\text { re-admission policy for } \\
\text { teenage mothers }\end{array}$ & 42 & 64.6 & 15 & 23.1 & 3 & 4.6 & 2 & 3.1 & 3 & 4.6 & 65 & 100 \\
\hline $\begin{array}{l}\text { Parents with stable } \\
\text { careers follow re- } \\
\text { admission policy for } \\
\text { teenage mothers }\end{array}$ & 39 & 60.0 & 18 & 27.7 & 5 & 7.7 & 2 & 3.1 & 1 & 1.5 & 65 & 100 \\
\hline $\begin{array}{l}\text { Family size affects re- } \\
\text { admission policy for } \\
\text { teenage mothers }\end{array}$ & 31 & 47.7 & & 29.2 & 4 & 6.2 & 5 & 7.7 & 6 & 9.2 & 65 & 100 \\
\hline $\begin{array}{l}\text { The parents with high } \\
\text { and stable income } \\
\text { follow the re-admission } \\
\text { policy for teenage } \\
\text { mothers }\end{array}$ & & 56.9 & 20 & 30.8 & 5 & 7.7 & 2 & 3.1 & 1 & 1.5 & 65 & 100 \\
\hline $\begin{array}{l}\text { Cultural background of } \\
\text { the parents determines } \\
\text { the level of policy } \\
\text { implementation. }\end{array}$ & 25 & 38.5 & & 29.2 & 15 & 23.1 & 3 & 4.6 & & 4.6 & 65 & 100 \\
\hline $\begin{array}{l}\text { Parents religious } \\
\text { background determine } \\
\text { the implementation of } \\
\text { re-admission policy }\end{array}$ & 20 & 30.8 & 18 & 27.7 & 17 & 26.2 & 3 & 4.6 & & 10.8 & 65 & 100 \\
\hline
\end{tabular}

Table 3 established that majority (64.6\%) and $60 \%$ of the respondents strongly agreed that educated parents and parents with stable careers respectively follow re-admission policy for teenage mothers. These results are in line with the results in Table 3 . This was followed by $56.9 \%$ who strongly agreed that, the parents with high and stable income follow the re-admission policy for teenage mothers. It was however noted that there were few (30.8\%) and $38.5 \%$ respondents who strongly agreed that parent's religious background and cultural background of the parents respectively determines the level of policy implementation of re-admission policy. These results agree with Ouma (2013) who argued that the factors affecting participation of the girl-child in secondary school education was based on socio-economic, socio-cultural, parents' level of education and distance from school factors.

Table 4: Family size and implementation of re-admission policy

\begin{tabular}{llrr}
\hline & & Family size & \multicolumn{2}{c}{$\begin{array}{c}\text { Implementation of re- } \\
\text { admission policy }\end{array}$} \\
\hline Family size & Pearson Correlation & 1 & $-.546(* *)$ \\
& Sig. (2-tailed) & & .000 \\
& $\mathrm{~N}$ & 95 & 95 \\
Implementation of re- & Pearson Correlation & $-.546(* *)$ & 1 \\
admission policy & & .000 & 95 \\
& Sig. (2-tailed) & $\mathrm{N}$ & 95 \\
\hline
\end{tabular}

** Correlation is significant at the 0.01 level (2-tailed).

Table 4 shows that there is a moderate negative relationship $\mathrm{r}(65)=-0.546, \mathrm{p}<0.05$ between family and implementation of re-admission policy of girls after teenage pregnancy in public secondary schools. We therefore reject Ho3. This means that the bigger the family sizes the lower the chances of re-admission of girls after teenage pregnancy. These results agree with Nyakioma (2011) who argued that family size contributes to the moral life of the girls and that most of these girls were from families with many children. The bigger the size of the family, the more likely that parent does not care much for their children's education. The major challenge they face is baby care. These girls find it difficult to balance education responsibilities and childcare. Most of the teenage mothers lack a person to baby-sit their babies as they go to school. They thus opt to stay and ultimately withdraw from school in order to vend for the child. 
Table 5: Girls awareness of the re-admission policy and implementation of re-admission policy.

\begin{tabular}{|c|c|c|c|}
\hline & & Girls awareness & $\begin{array}{l}\text { Implementation of } \\
\text { re-admission policy }\end{array}$ \\
\hline \multirow[t]{3}{*}{ Girls' awareness } & Pearson's Correlation & 1 & $.852(* *)$ \\
\hline & Sig. (2-tailed) & & .000 \\
\hline & $\mathrm{N}$ & 65 & 65 \\
\hline \multirow{3}{*}{$\begin{array}{l}\text { Implementation of re- } \\
\text { admission policy }\end{array}$} & Pearson Correlation & $.852(* *)$ & 1 \\
\hline & Sig. (2-tailed) & .000 & \\
\hline & $\mathrm{N}$ & 65 & 65 \\
\hline
\end{tabular}

** Correlation is significant at the 0.01 level (2-tailed).

Table 5 shows that there is a strong positive relationship $\mathrm{r}(65)=0.852, \mathrm{p}<0.05$ between girls' awareness and implementation of re-admission policy of girls after teenage pregnancy in public secondary schools. This means that awareness increases the re-admission of girls after teenage pregnancy. These results agree with Omwancha (2012) who argued that, there was lack of awareness and understanding of both the policy and the guidelines and that lack of awareness was preventing teenage mothers from returning to school.

\subsection{Conclusions and Recommendations}

Based on the findings of this study, the researcher concluded that the family based determinants, which included; Parents Socio-Economic Status, Principals' opinion, Family Size and awareness of girls on the re-admission policy significantly influenced the implementation of the re-admission policy of girls after teenage pregnancy in public secondary schools. The higher the education level of parents and the social economic level positively influenced the implementation of the policy on re-admission of girls after teenage pregnancy in public secondary. The size of the family also determined the level of implementation of readmission policy of girls after teenage pregnancy. The study recommends that schools should follow their girls who become pregnant in school and ensure that they come back after delivery. Schools should also sensitize their parents on the implementation of the policy on re-admission of girls after teenage pregnancy in public secondary schools.

\section{References}

County Director of Education, Kitui. (2013). Education Sector Report: on Secondary School Dropouts. County Government Printers, Kitui County, Kenya.

County Director of Education, Kitui. (2015). Education Sector Report: on Secondary School Dropouts. County Government Printers, Kitui County, Kenya.

Forum for African Women Educationalists (2014). World Literacy Summit, Oxford, UK. Forum for African Women. Washington, D.C: Center for Global Development

Inziani, A. C. (2013). The Effect of Socio-economic Factors on Students' Participation in Public Day Secondary Schools in Embakasi District of Nairobi County. MED Research Project- Unpublished. University of Nairobi.

Lewis, M. A., \& Lockheed, M. E. (2006). Inexcusable Absence: Why 60 million girls still aren't in school and what to do about it. Washington, D.C: Center for Global Development.

Lewis, M. A., \& Lockheed, M. E. (2007). Exclusion, Gender and Schooling: Case Studies from the Developing World. Washington, DC: Center for Global Development.

Mieke, V. (2006). A Commentary on the United Nations Convention on the Rights of the Child. Article 28 the Right to Education. Boston: Nijhoff Publishers.

Ministry of Education (2010). Policy Framework for Education on Enrollment in Primary and Secondary Schools, Kenya. Government printers, Nairobi.

Muema A, Kasivu, G. M. \& Mwanza R (2019). Influence of Motivation on Teachers' Involvement in CoCurricular Activities in Public Secondary Schools in Matungulu Sub County, Machakos County, Kenya. International Journal of Education and Research. ISSN: 2411-5681Vol.\& No.5 2019

Nyakioma, I.K (2012). Measures to Improve Pregnant and Teenage Mothers' Participation in Secondary Education: A Case of Etago Division Kisii County. MED Research Project- Unpublished. University of Nairobi.

Nyakio, Factors influencing head teachers' levels of job satisfaction in public primary schools in Kinangop District, Nyandarua County, Kenya. MED Research Project- Unpublished. University of Nairobi.

United Nations International Children's Fund, (2010) Annual Report. Achieving Millennium Development Goals. (MDGS). Child friendly schools manual, New York, UNICEF.

Nguli F, Kasivu, G. M. \& Kamau L (2018). Influence of Teacher Demographic Factors on Integration of Information Communication and Technology in Teaching in ICT Champion Schools in Machakos SubCounty. Scholarly Research Journal for Interdisciplinary Studies, Online ISSN 2278-8808, SJIF $2018=$ 6.371, www.srjis.com .Peer Reviewed Journal, Nov-Dec, 2018, VOL- 6/48

Republic of Kenya (2007). Gender Policy in Education. Nairobi: Government Printer.

Njagi, S, N., Mwania, J.M., Manyasi, B., \& Mwaura, K. (2017) Parenting Styles as Predictors of Risky Sexual 
Behaviors Among Selected Public Secondary School Students in Embu County, Kenya. International Journal of Asian Social Science, Vol. 7, No. 11, 910-920, ISSN (e): 2224-4441 ISSN (p): 2226-5139, DOI: 10.18488/journal.1.2017.711.910.920

Njagi, S. N., \& Mwania, J.M (2017). Parenting Styles of Predators of Dropout Rate among Selected Public Secondary School Students in Embu County, Kenya. International Journal of Education and Research, vol 5 No 12, 15-30, ISSN: 2411-5681, December 2017.

Omwancha, M. O. (2012). The Implementation of an Educational Re-entry Policy for Girls after Teenage Pregnancy: A Case Study of Public Secondary Schools in Kuria District, Kenya. MED Research ProjectUnpublished. University of Nairobi.

Ouma, G.O. (2013). Factors Affecting Participation of Girl-Child in Secondary School Education in Migori District, Migori County, Kenya. MED Research Project- Unpublished. University of Nairobi. 